\title{
Antiretroviral tolerability and efficacy after switch to saquinavir in PI-experienced patients: 48-week analysis of the German Rainbow Cohort
}

\author{
C Stephan*1, H Jaeger ${ }^{2}$, A Carganico3 ${ }^{3}$ G Knecht ${ }^{4}$, T Lutz ${ }^{4}$, C Mayr ${ }^{5}$, \\ FA Mosthaf ${ }^{6}$, S Koeppe ${ }^{7}$, M Mueller ${ }^{8}$, E Wolf ${ }^{9}$, A Tappe ${ }^{10}$, E Wellmann ${ }^{10}$ and \\ H Knechten ${ }^{11}$
}

\begin{abstract}
Address: ${ }^{1}$ Klinikum der Johann-Wolfgang-Goethe-Universitaet, Frankfurt, Germany, ${ }^{2}$ HIV Research and Clinical Care Centre Munich, Munich, Germany, ${ }^{3}$ Praxis Dres. S. Dupke/A. Carganico/A. Baumgarten, Berlin, Germany, ${ }^{4}$ Infektiologikum Frankfurt, Frankfurt a. M., Germany, ${ }^{5} \mathrm{MVZ-}$ Aerzteforum Seestrasse Dres. C. Mayr/PD W. Schmidt, Berlin, Germany, ${ }^{6}$ Praxis Dres. F.A. Mosthaf/M. Procaccianti/K. Zutavern-Bechtold, Karlsruhe, Germany, ${ }^{7}$ Praxis Dres. S. Koeppe/P. Kreckel, Berlin, Germany, ${ }^{8}$ Praxis Dres. B. Frietsch/A. Ulmer/M. Mueller, Stuttgart, Germany, ${ }^{9}$ MUC Research, Munich, Germany, ${ }^{10}$ Roche Pharma AG, Grenzach-Wyhlen, Germany and ${ }^{11}$ Praxenzentrum Blondelstrasse (PZB), Aachen, Germany

* Corresponding author
\end{abstract}

from Ninth International Congress on Drug Therapy in HIV Infection

Glasgow, UK. 9-13 November 2008

Published: 10 November 2008

Journal of the International AIDS Society 2008, I I (SuppI I):P25 doi: I0.I I86/I758-2652-I I-SI-P25

This abstract is available from: http://www.jiasociety.org/content/II/SI/P25

(c) 2008 Stephan et al; licensee BioMed Central Ltd.

\section{Purpose of the study}

The aim of the Rainbow Cohort is to assess the tolerability and efficacy of initiating treatment with, or switching treatment to the saquinavir (SQV) $500 \mathrm{mg}$ film-coated tablet formulation. We present the final 48-week subgroup analysis of PI-experienced, but SQV-naïve patients.

\section{Methods}

Multicenter, prospective, open label, observational cohort study. Tolerability assessment included changes in lipids - stratified according to baseline (BL) levels - from BL to week 48. Efficacy assessment included changes in CD4 count and viral load (VL). Changes to baseline were tested for significance with Wilcoxon signed rank test.

\section{Summary of results}

Median BL characteristics from evaluable patients $(\mathrm{n}=$ 426): $84 \%$ male; age 43 years; time since first HIV diagnosis 9 years (IQR 4; 14); VL $599 \mathrm{cp} / \mathrm{mL}(\mathrm{IQR}<50 ; 31,291)$; $\mathrm{VL}<50 \mathrm{cp} / \mathrm{mL} 33.6 \%$; CD4 count 320 cells $/ \mathrm{mm}^{3}$ (IQR 177; 506). Week 48 results: Median CD4 increase was +61 cells/mm ${ }^{3}$ (IQR -9; 170; $\mathrm{p}<0.01$ ); $60.3 \%$ of patients achieved a VL $<50 \mathrm{cp} / \mathrm{mL}$ (ITT, LOCF analysis). SQV treatment was stopped in $22 \%$ of the patients ( $6 \%$ due to side- effects, 4\% due to virological failure). Stratified according to BL triglyceride levels, median changes (ITT, LOCF analysis) were $+14 \mathrm{mg} / \mathrm{dL}(\mathrm{IQR}-8 ; 57)$ for patients with $<200$ $\mathrm{mg} / \mathrm{dL}(\mathrm{p}<0.01 ; \mathrm{n}=196) ;-50 \mathrm{mg} / \mathrm{dL}(\mathrm{IQR}-139 ; 0)$ for patients with $200-750 \mathrm{mg} / \mathrm{dL}(\mathrm{p}<0.01 ; \mathrm{n}=136)$ and $656 \mathrm{mg} / \mathrm{dL}$ (IQR $-1024 ; 0$ ) for patients with $>750 \mathrm{mg} / \mathrm{dL}$ $(\mathrm{p}<0.01 ; \mathrm{n}=15)$, respectively. Stratified according to BL total cholesterol levels, median changes (ITT, LOCF analysis) were $+16 \mathrm{mg} / \mathrm{dL}$ (IQR -3; 43) for patients with $<200$ $\mathrm{mg} / \mathrm{dL}(\mathrm{p}<0.01 ; \mathrm{n}=206) ;-3 \mathrm{mg} / \mathrm{dL}(\mathrm{IQR}-25 ; 25)$ for patients with $200-300 \mathrm{mg} / \mathrm{dL}(\mathrm{p}=0.4 ; \mathrm{n}=121)$ and -47 $\mathrm{mg} / \mathrm{dL}(\mathrm{IQR}-87 ;-4$ ) for patients with $>300 \mathrm{mg} / \mathrm{dL}$ (p < $0.01 ; \mathrm{n}=11)$, respectively. No significant changes of ALT, AST, $\gamma$-GT, or bilirubin were observed. See Figure 1.

\section{Conclusion}

These data confirm that $S Q V / r$ is effective and well tolerated in PI-experienced, SQV-naïve patients in a real-life clinical setting. Most relevant improvements in triglycerides and total cholesterol levels were observed in patients with baseline grade III-IV elevation. 


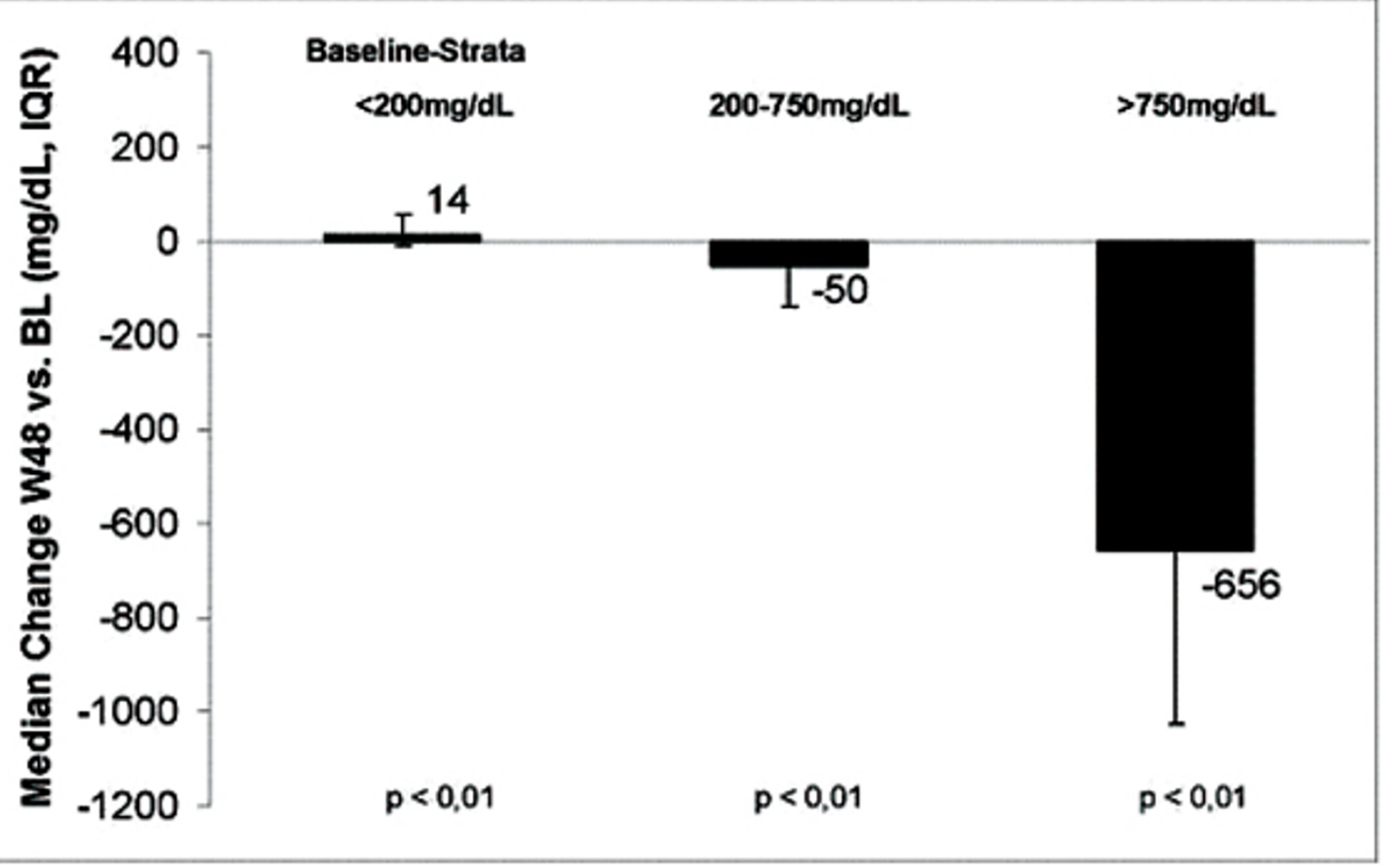

Figure I

Median changes in triglycerides (LOCF) from baseline to week 48 - stratified according to baseline level - after start of an $\mathrm{SQV} / \mathrm{r}$ containing antiretroviral therapy in $\mathrm{PI}$-pretreated, but SQV-naïve patients.

Publish with Biomed Central and every scientist can read your work free of charge

"BioMed Central will be the most significant development for disseminating the results of biomedical research in our lifetime."

Sir Paul Nurse, Cancer Research UK

Your research papers will be:

- available free of charge to the entire biomedical community

- peer reviewed and published immediately upon acceptance

- cited in PubMed and archived on PubMed Central

- yours - you keep the copyright
BioMedcentral 